Www.jmscr.igmpublication.org

Index Copernicus Value: 79.54

ISSN (e)-2347-176x ISSN (p) 2455-0450

crossref DOI: https://dx.doi.org/10.18535/jmscr/v7i6.66

\title{
The relevance of Chronic Prostatitis Histology in Transrectal prostatic biopsy: A hospital-based retrospective study in Patna
}

\author{
Authors \\ Dr Ahsan Ahmad ${ }^{1}$, Dr Khalid Mahmood ${ }^{2 *}$, Dr Gaurav Kumar Mishra ${ }^{3}$, \\ Dr Gaurav Singh ${ }^{3}$
}

${ }^{1}$ Associate Professor, Department of Urology, Indira Gandhi Institute of Medical Sciences, Patna, Bihar

${ }^{2}$ Associate Professor, Department of Urology, Indira Gandhi Institute of Medical Sciences, Patna, Bihar

${ }^{3}$ Post Graduate Trainee, Department of Urology, Indira Gandhi Institute of Medical Sciences, Patna, Bihar

*Corresponding Author

Dr Khalid Mahmood

Indira Gandhi Institute of Medical Sciences Campus, D type6/4, Sheikhpura, Patna, Bihar 800014, India

\begin{abstract}
Objective: There was a link among Level of prostate cancer (PCa), symptoms of lower urinary tract and chronic prostatitis $(C P)$ histology, despite there was uncertainty with this clinical meaning. We pursue a retrospective analysis of existing patient's data at a Patna based hospital to establish the link between diagnosis of $P C a$ and role of $C P$.

Methods: Hospital database were used to fetch required data for patients who had undergoing prostate biopsy with all histological findings of chronic prostatitis from April 2015 to March 2019. Patients were categorised on basis of Without Chronic Prostatitis and With Chronic Prostatitis. Using univariate and multivariate analyses association between CP and PCa diagnosis was determined.

Result: 657 patients were selected whose average mean age was $68 \pm 8.23$ years with PSA level of $8.8 \pm 1.1$ $\mathrm{ng} / \mathrm{ml}$. Entire population were categorised on basis of Without Chronic Prostatitis $(N=255)$ and With Chronic Prostatitis (N=402). Between group's difference of IPSS score, age, prophylactic antibiotic use, PSA, transurethral catheter at biopsy or infectious complications, alpha-blocker or 5- $\alpha$-reductase inhibitor therapy and comorbidities were statistically insignificant, whereas number of cores taken, cancer diagnosis, prostate volume, suspicious digital prostate exam, previous biopsy and hospitalizations and Gleason score $>=7$ differences were found the be statistically significant. Protective effect between CP and diagnosis of PCa was shown by a multivariate analysis model (HR 0.14, $p=<0.01)$.

Conclusion: This observation suggest that PCa diagnosis is inversely related to histological finding of CP. Keywords: Prostate Biopsy; Chronic Prostatitis, Prostate Cancer.
\end{abstract}

\section{Introduction}

When prostate-specific antigen (PSA) level rises above $4 \mathrm{ng} / \mathrm{ml}$ in male patients they has been recommended for prostatic biopsy after an assessment of life expectancy, co-morbidity and a detailed discussion regarding the implications of a biopsy and its result ${ }^{[1]}$. Data from prostate cancer prevention trial reviles that there was no normal in PSA level and there was always high risk of prostate cancer development chance with an existing PSA level ${ }^{[2]}$. 
The National Institutes of Health Classification System for prostatitis classified prostatitis in four category which are category I (acute bacterial prostatitis), category II (chronic bacterial prostatitis), category III (chronic prostatitis/ chronic pelvic pain syndrome - CP/CPPS) and category IV asymptomatic inflammatory prostatitis ${ }^{[3,4]}$. The evaluation of a patient with category I and category II bacterial prostatitis consists of history and physical examination and urine culture for lower urinary tract localization cultures, respectively ${ }^{[5]}$. The various investigative procedures used in clinical, laboratory, and imaging evaluations for the patient presenting with chronic pelvic pain are discussed and categorized as mandatory, recommended, or optional procedures ${ }^{[6]}$. These categories primarily serve to rule out underlying pathology because there is no diagnostic test for chronic prostatitis/chronic pelvic pain syndrome (CPPS) [7].

There was a link among Level of prostate cancer (PCa), symptoms of lower urinary tract and chronic prostatitis (CP) histology, despite there was uncertainty with this clinical meaning. We pursue a retrospective analysis of existing patient's data at a Patna based hospital to establish the link between diagnosis of $\mathrm{PCa}$ and role of $\mathrm{CP}$.

\section{Methods}

Hospital database were used to fetch required data for patients who had undergoing prostate biopsy with all histological findings of chronic prostatitis from April 2015 to March 2019. Patients were categorised on basis of Without Chronic Prostatitis and With Chronic Prostatitis. Procedure technique and antibiotic prophylaxis which was followed and persuade was reported at early by several time ${ }^{[8,9]}$. CP was defined as "Category IV" according to the NIH classification of prostatitis syndromes (asymptomatic inflammatory prostatitis). Using univariate and multivariate analyses association between $\mathrm{CP}$ and $\mathrm{PCa}$ diagnosis was determined. Value was consider as statistically significant when $\mathrm{p}<0.05$. Statistical analysis was made with the aid of SPSS $®$ v. 17.0 (IBM®, New York) program.

\section{Result}

657 patients were selected whose average mean age was $68 \pm 8.23$ years with PSA level of $8.8 \pm 1.1$ $\mathrm{ng} / \mathrm{ml}$. Entire population were categorised on basis of Without Chronic Prostatitis ( $=255)$ and With Chronic Prostatitis ( $\mathrm{N}=402)$. Table 1 describes all the clinical characteristics. Except for number of previous biopsies $(\mathrm{p}=0.04)$ and previous hospital admissions $(\mathrm{p}=0.01)$, there were no differences.

Table 1: Clinical characteristics

\begin{tabular}{|c|c|c|c|}
\hline Characteristics. & $\begin{array}{l}\text { Without } \\
\text { Chronic } \\
\text { Prostatitis } \\
(n=255)\end{array}$ & $\begin{array}{l}\text { With } \\
\text { Chronic } \\
\text { Prostatitis } \\
(n=402)\end{array}$ & $\begin{array}{c}\mathbf{p} \\
\text { value }\end{array}$ \\
\hline Age, years & $68 \pm 8.28$ & $68 \pm 8.21$ & 0.96 \\
\hline $\mathrm{PSA}, \mathrm{ng} / \mathrm{dl}$ & $8.5 \pm 1.1$ & $8.9 \pm 1.1$ & 0.49 \\
\hline PIPSS, total & $7.8 \pm 6.0$ & $8.6 \pm 5.5$ & 0.34 \\
\hline \multicolumn{4}{|c|}{ LUTS therapy (alpha-blockers) } \\
\hline Yes & 159 & 269 & \multirow{3}{*}{0.83} \\
\hline No & 93 & 129 & \\
\hline Unknown & 3 & 4 & \\
\hline \multicolumn{4}{|c|}{ LUTS therapy (5-ARI) } \\
\hline Yes & 18 & 26 & \multirow{3}{*}{0.54} \\
\hline No & 235 & 372 & \\
\hline Unknown & 2 & 4 & \\
\hline \multicolumn{4}{|c|}{ Transurethral catheter at prostate biopsy } \\
\hline Yes & 13 & 29 & \multirow{3}{*}{0.67} \\
\hline No & 239 & 368 & \\
\hline Unknown & 3 & 5 & \\
\hline \multicolumn{4}{|c|}{ Hospitalization 1 month before prostate biopsy } \\
\hline Yes & 33 & 33 & \multirow{3}{*}{0.01} \\
\hline No & 219 & 365 & \\
\hline Unknown & 3 & 3 & \\
\hline \multicolumn{4}{|c|}{ Previous biopsies number } \\
\hline Yes & 206 & 294 & \multirow{3}{*}{0.04} \\
\hline No & 46 & 105 & \\
\hline Unknown & 3 & 3 & \\
\hline
\end{tabular}

Procedure characteristics including histological information and indications for TRPB were summarized in table $2 \& 3$, respectively. 
Table 2

\begin{tabular}{|c|c|c|c|}
\hline Characteristics. & $\begin{array}{l}\text { Without } \\
\text { Chronic } \\
\text { Prostatitis } \\
(\mathbf{n}=\mathbf{2 5 5}) \\
\end{array}$ & $\begin{array}{l}\text { With } \\
\text { Chronic } \\
\text { Prostatitis } \\
(\mathbf{n}=402) \\
\end{array}$ & p value \\
\hline \multicolumn{4}{|l|}{ PCa diagnosis } \\
\hline Yes & 147 & 62 & \multirow{2}{*}{$<0.01$} \\
\hline No & 108 & 340 & \\
\hline \multicolumn{4}{|l|}{ Gleason score $\geq 7$} \\
\hline$<7$ & 104 & 49 & \multirow{3}{*}{0.21} \\
\hline$\geq 7$ & 40 & 12 & \\
\hline Unknown & 3 & 1 & \\
\hline \multicolumn{4}{|l|}{ Atrophy } \\
\hline Yes & 79 & 265 & \multirow{2}{*}{$<0.01$} \\
\hline No & 176 & 137 & \\
\hline \multicolumn{4}{|l|}{ Hyperplasia } \\
\hline Yes & 145 & 390 & \multirow{2}{*}{$<0.01$} \\
\hline No & 110 & 12 & \\
\hline \multicolumn{4}{|l|}{ PIN/ASAP } \\
\hline Yes & 18 & 12 & \multirow{2}{*}{0.16} \\
\hline No & 237 & 390 & \\
\hline \multicolumn{4}{|c|}{$\begin{array}{llr}\text { PCa: Prostate Cancer; PIN: Prostatic } & \text { Intraepithelial } \\
\text { Neoplasia; } & \text { ASAP: } & \text { Atypical } \\
\text { Small Acinar Proliferation of the prostate } & \end{array}$} \\
\hline
\end{tabular}

Table 3: Procedure characteristics

\begin{tabular}{|c|c|c|c|}
\hline Characteristics. & $\begin{array}{c}\text { Without } \\
\text { Chronic } \\
\text { Prostatitis } \\
(\mathbf{n}=255) \\
\end{array}$ & $\begin{array}{c}\text { With } \\
\text { Chronic } \\
\text { Prostatitis } \\
(\mathbf{n}=402) \\
\end{array}$ & $\begin{array}{c}\mathbf{p} \\
\text { value }\end{array}$ \\
\hline $\begin{array}{l}\text { Number of cores } \\
\text { taken }\end{array}$ & $13.9 \pm 3.5$ & $15 \pm 3.6$ & $<0.01$ \\
\hline $\begin{array}{l}\text { Prostatic volume, } \\
\mathrm{cm} 3\end{array}$ & $48.2 \pm 31.6$ & $53.7 \pm 27.3$ & 0.05 \\
\hline \multicolumn{4}{|l|}{ Antibiotic prophylaxis } \\
\hline $\begin{array}{l}\text { Piperacillin/ } \\
\text { tazobactam }\end{array}$ & 236 & 376 & \multirow{3}{*}{0.81} \\
\hline Others & 16 & 22 & \\
\hline Unknown & 3 & 4 & \\
\hline \multicolumn{4}{|c|}{ DRE suspicious of malignancy } \\
\hline Yes & 93 & 100 & \multirow{3}{*}{0.02} \\
\hline No & 159 & 298 & \\
\hline Unknown & 3 & 4 & \\
\hline \multicolumn{4}{|c|}{ Early infectious complications* } \\
\hline \multicolumn{3}{|l|}{ Yes } & \multirow{3}{*}{0.46} \\
\hline No & 231 & & \\
\hline Unknown & 1 & 0 & \\
\hline $\begin{array}{l}( \pm \text { SD): Standard } \\
\text { Examination. } \\
\text { * Includes positive } \\
\text { clinical urinary tract }\end{array}$ & $\begin{array}{l}\text { Deviation; } \\
\text { rine cultures } \\
\text { ffection }\end{array}$ & $\begin{array}{l}\text { RE: Digital } \\
\text { acute pros }\end{array}$ & $\begin{array}{l}\text { Rectal } \\
\text { titis or }\end{array}$ \\
\hline
\end{tabular}

Between group's difference of IPSS score, age, prophylactic antibiotic use, PSA, transurethral catheter at biopsy or infectious complications, alpha-blocker or 5- $\alpha$-reductase inhibitor therapy and comorbidities were statistically insignificant, whereas number of cores taken, cancer diagnosis, prostate volume, suspicious digital prostate exam, previous biopsy and hospitalizations and Gleason score $>=7$ differences were found the be statistically significant. Protective effect between $\mathrm{CP}$ and diagnosis of $\mathrm{PCa}$ was shown by a multivariate analysis model $(\mathrm{HR} 0.14, \mathrm{p}=<0.01)$.

\section{Discussion}

Prostate cancer remains a major concern of public health. Tremendous mortality, morbidity and economic costs are associated with palliation of the disease, screening, treatment ${ }^{[10,11]}$. Aetiological factors that initiate and enhance the progression of this malignancy are beginning to emerge, with strong evidence that chronic inflammation and uncontrolled cell proliferation within the prostate are linked to initiation and neoplastic conversion ${ }^{[12]}$. This evidence suggests that dietary strategies targeting inflammation and proliferation would be effective in limiting $\mathrm{CaP}$ development ${ }^{[13-16]}$. We are often confronted with the association of abnormal PSA levels and biopsies that reveal no PC but only inflammation. The ratio of free-to-total PSA, calculated as percentage of fPSA, has been suggested as a useful tool for differentiating between $\mathrm{PC}$ and $\mathrm{BPH}$, because the ratio is lower in $\mathrm{PC}$ than in $\mathrm{BPH}^{[17]}$.

A recent meta-analysis had confirm that stromal prostatic tissue release of cytokines which can develop prostatic hyperplasia with subsequent neo-vascularization ${ }^{[15]}$. This study found a clear association between BPH development, chronic prostatic inflammation and increasing LUTS severity. Furthermore it can be concluded the chronic inflammation can predict the intensity of the medical therapy received by BPH patients. Lower frequency of $\mathrm{PCa}$ was also found in patients with histological chronic prostatitis in this 
study. This may be related with higher prostate size and higher frequency of prostatic hyperplasia both well-known factors associated with lower incidence of PCa. This study includes all patients who underwent a prostatic biopsy irrespective of the decision-making matrix for the individual patient. Hence, this study is a snapshot analysis of Indian patients undergoing prostatic biopsy in clinical practice at a tertiary care hospital.

\section{Conclusion}

This observation suggest that PCa diagnosis is inversely related to histological finding of $\mathrm{CP}$. Histological CP could be associated to other pathological findings in TRPB.

\section{Disclosure}

The author has no potential conflicts of interest to disclose.

\section{Reference}

1. Catalona WJ, Hudson MA, Scardino PT, Richie JP, Ahmann FR, Flanigan RC, et al. Selection of optimal prostate specific antigen cutoffs for early detection of prostate cancer: Receiver operating characteristic curves. J Urol 1994;152:2037-42.

2. Thompson IM, Ankerst DP, Chi C, Tangen CM, Lucia MS, Feng Z, et al. Assessing prostate cancer risk: Results from the Prostate Cancer Prevention Trial. J Natl Cancer Inst 2006;98:529-34.

3. Krieger JN, Nyberg Jr L, Nickel JC. NIH consensus definition and classification of prostatitis JAMA. 1999; 282: 236-237.

4. McNaughton Collins, M., Fowler, F.J. Jr, Elliott, D.B. et al, Diagnosing and treating chronic prostatitis (do urologists use the 4glass test?) . Urology. 2000;55:403-407

5. Litwin, M.S., McNaughton-Collins, M., Fowler, F.J. Jr et al, The National Institutes of Health chronic prostatitis symptom index (development and validation of a new outcome measure.
Chronic Prostatitis Collaborative Research Network) . J Urol. 1999;162:369-375

6. Nickel, J.C., McNaughton-Collins, M., Litwin, S.M. Development and use of a validated outcome measure for prostatitis. J Clin Outcomes Manag. 2001;8:30-37

7. Nickel J: Special report on prostatitis: state of the art. Rev Urol 3: 94-98, 2001

8. Rodriguez-Covarrubias F, GonzalezRamirez A, Aguilar-Davidov B, Castillejos-Molina RA, Sotomayor M, Feria-Bernal G. Extended sampling at first biopsy improves cancer detection rate: results of a prospective, randomized trial comparing 12 versus 18-core prostate biopsy. J Urol. 2011; 185: 2132-2136.

9. Aguilar DB, Castillejos MR, Sotomayor M, Feria BG, Rodriguez-Covarrubias F. A single dose of piperacillin-tazobactam for the prophylaxis of febrile complications in transrectal needle biopsy of the prostate. J Urol. 2009; 181: 802.

10. J E Elkahwaji, R J Hauke\& C M Brawner. Chronic bacterial inflammation induces prostatic intraepithelial neoplasia in mouse prostate. British Journal of Cancer volume 101, pages 1740-1748 (17 November 2009).

11. Nelson WG, De Marzo AM, DeWeese TL (2001) The molecular pathogenesis of prostate cancer: implications for prostate cancer prevention. Urology 57: 39-45

12. Nelson WG, De Weese TL, De Marzo AM (2002) The diet, prostate inflammation, and the development of prostate cancer. Cancer Metastasis Rev 21: 3-16

13. Cheville JC, Bostwick DG (1995) Postatrophic hyperplasia of the prostate. A histologic mimic of prostatic adenocarcinoma. Am J SurgPathol 19: 1068-1076.

14. Bartsch G, Horninger W, Klocker H, Pelzer A, Bektic J, Oberaigner W, Schennach H, Schäfer G, Frauscher F, Boniol M, Severi G, Robertson C, Boyle 
P, Tyrol Prostate Cancer Screening Group (2008) Tyrol Prostate Cancer Demonstration Project: early detection, treatment, outcome, incidence and mortality. BJU Int 101(7): 809-816

15. Ames BN, Gold LS, Willett WC (1995) The causes and prevention of cancer. Proc Nat AcadSci USA 92: 5258-5265

16. De Nunzio C, Albisinni S, Gacci M, Tubaro A. The role of inflammation in the progression of benign prostatic hyperplasia. Curr Bladder Dysfunc Rep. 2013; 8: 142-149.

17. Catalona WJ. Clinical utility of measurements of free and total prostatespecific antigen (PSA): a review. Prostate Suppl. 1996;7:64-69. 